

\section{DISCLAIMER}

This report was prepared as an account of work sponsored by an agency of the United States Government. Neither the United States Government nor any agency Thereof, nor any of their employees, makes any warranty, express or implied, or assumes any legal liability or responsibility for the accuracy, completeness, or usefulness of any information, apparatus, product, or process disclosed, or represents that its use would not infringe privately owned rights. Reference herein to any specific commercial product, process, or service by trade name, trademark, manufacturer, or otherwise does not necessarily constitute or imply its endorsement, recommendation, or favoring by the United States Government or any agency thereof. The views and opinions of authors expressed herein do not necessarily state or reflect those of the United States Government or any agency thereof. 


\section{DISCLAIMER}

Portions of this document may be illegible in electronic image products. Images are produced from the best available original document. 
Reference to a company or product name does not imply approval or recommendation of the product by Union Carbide Corporation or the Department of Energy to the exclusion of others that may meet specifications.

Printed in the United States of America. Available from National Technical Information Service

U.S. Department of Commerce

5285 Port Royal Road, Springfield, Virginia 22161

Price: Printed Copy $\$ 4.00$; Microfiche $\$ 3.00$

This report was prepared as an account of work sponsored by an agency of the United States Government. Neither the United States Government nor any agency thereof, nor any of their employees, nor any of their contractors, subcontractors, or their employees, makes any warranty, express or implied, nor assumes any legal liability or responsibility for any third party's use or the results of such use of any information, apparatus, product or process disclosed in this report, nor represents that its use by such third party would not infringe privately owned rights. 


\title{
X-RAY TRANSMISSION/SCATTERING TECHNIQUE FOR THICKNESS-INDEPENDENT DENSITY MEASUREMENT
}

\author{
Ł. J. Giacómelll \\ Instrumentation and Characterization Department \\ Y-12 Development Division
}

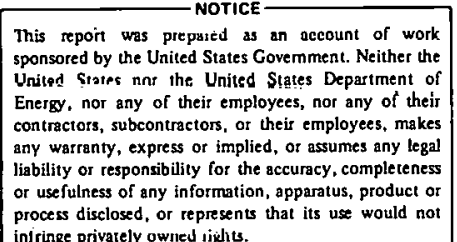

iniringe privarely owned lights.

\section{Oak Ridge Y-12 Plant}

P. O. Box Y, Oak Ridge, Tennessee 37830

Prepared for the Department of Energy Under US Government renntract W-7405-eng-26 


\begin{abstract}
A nondestructive technique, using penetrating $X$ radiation, has been developed to measure the density uniformity of low- $Z$, compressible materials that is independent of material thickness. Thickness independence is achieved by simultaneously monitoring the transmitted and scattered $X$ rays. Results on samples of pressed carbon materials have demonstrated that there is the expected linear relationship between measured quantities and material density, independent of material thickness, and that this is a viable means of measuring density uniformity.
\end{abstract}


CONTENTS

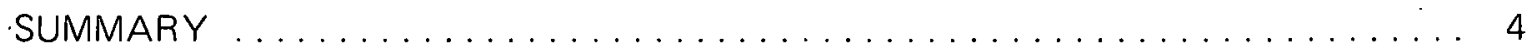

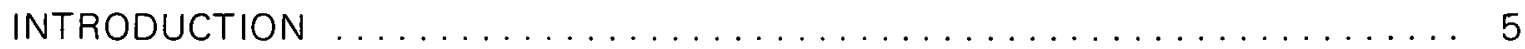

X-RAY TRANSMISSION/SCATTERING TECHNIQUE FOR MEASURING DENSITY . . 6

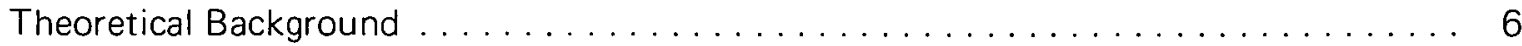

Instrumentation .............................. 7

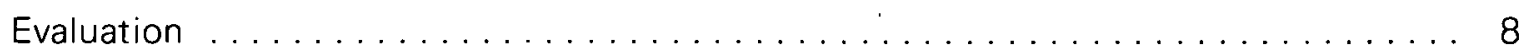

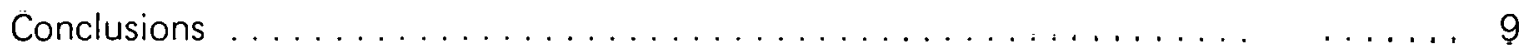

ACKNOWLEDGEMENTS $\ldots \ldots \ldots \ldots \ldots \ldots \ldots \ldots \ldots \ldots \ldots \ldots \ldots \ldots$ 


\section{SUMMARY}

Penetrating $X$ radiation is extensively used to obtain density information from a variety of different materials. Most commonly used methods involve monitoring $X$-ray transmission or scattering. A new technique which monitors both $X$-ray transmission and scattering has been developed to measure density uniformity of low-Z materials directly and independent of the material thickness. Samples of pressed carbon materials having a wide range of densities and thicknesses were used to evaluate this technique. Results have demonstrated that there is the expected linear relationship between measured quantities and density, independent of material thickness. Using this technique, density variations in pressed carbon materials have been established. 


\section{INTRODUCTION}

The technique utilizing penetrating radiation was developed to solve the problem of nondestructively measuring density uniformity in a variety of low- $Z$, compressible materials. No existing technique could adequately make this measurement. The measurement concept is based on simultaneously monitoring transmitted and scattered $X$ radiation. Samples of pressed carbon materials were used to evaluate this concept, and the viability of using this technique to measure density uniformity has been demonstrated. This technique offers greater precision and is more generally applicable to a wide variety of conditions than existing techniques that monitor scattering alone. This report describes the measurement concept and the method of evaluation. 


\section{X-RAY TRANSMISSION/SCATTERING TECHNIQUE FOR MEASURING DENSITY}

\section{THEORETICAL BACKGROUND}

The technique for measuring material density involves the use of penetrating $X$ radiation. $A$ highly collimated $X$-ray beam is used to penetrate a sample material. The beam undergoes absorption and scattering in the sample, and is transmitted with reduced intensity. The amount of absorption and. scattering that occurs depends on several variables, including the density of the sample. A scheme has been selected so that this measurement is insensitive to all variables but density, and the sample density can be determined directly and independently of sample thickness by measuring the ratio of scattered to transmitted $X$.rays emitted from the sample.

Figure 1 is a diagram of the scheme that is being used. The expression for the ratio of scattered to transmitted $X$ rays is:

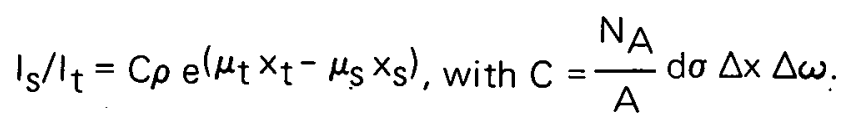

In this expression, $\rho$ represents the density of the scattering volume, $\Delta V$, as defined by the detectors' collimations; NA. Avogadro's number; $A$, the atomic weight of the material; do, the differential scattering cross section; $\Delta x$, the thickness of the scattering volume; and, $\Delta \omega$, the solid angle subtended by the scattered $X$-ray collimator slit. The quantities $\mu_{t}$ and $\mu_{\mathrm{S}}$ and $\mathrm{x}_{\mathrm{t}}$ and $\mathrm{x}_{\mathrm{s}}$ are, respectively, the linear attenuation coefficients for the transmitted and scattered $X$ rays and the path lengths of the transmitted and scattered $X$ rays within the sample from the scattering volume to the sample surface. But, $\mu_{\mathrm{s}} \approx \mu_{\mathrm{t}}$ and the sample material can be easily positioned so that $\mu_{\mathrm{t}} \mathrm{x}_{\mathrm{t}}=\mu_{\mathrm{s}} \times_{\mathrm{S}}$. In this case:

$$
I_{s} / I_{t}=C \rho,
$$

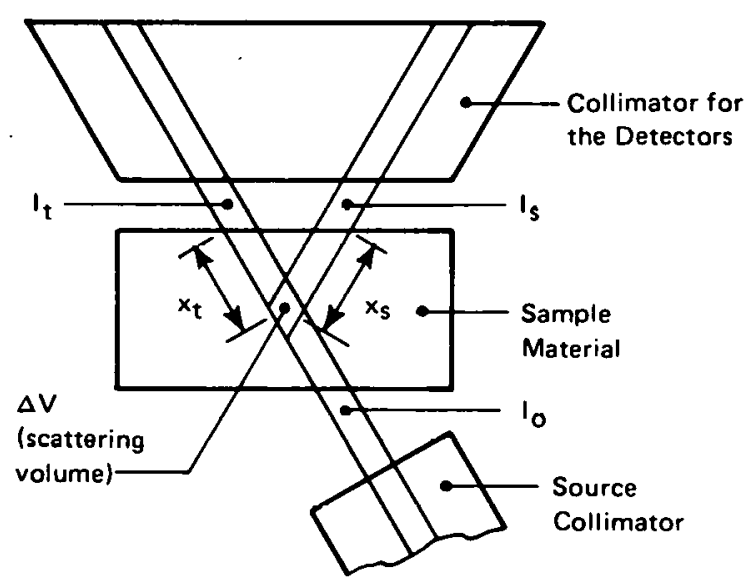

Figure 1. SCHEME FOR THE DENSITY MEASURE-

where, because the geometry and material MENT. are fixed, $C$ is a constant. So, for the scheme just described, the ratio of scattered to transmitted $X$ rays from a sample material is directly proportional to the density of that material. Therefore, the measurement is independent of thickness and the density is obtained directly. The value of $C$ is found experimentally by using a set of standards having known densities. (Each different material requires its own set of standards.) 


\section{INSTRUMENTATION}

Figure 2 provides a view of the entire measurement system; a block diagram of the principal components is presented in Figure 3. The $\mathrm{X}$-ray source is a GE 75-kV X-ray machine with a

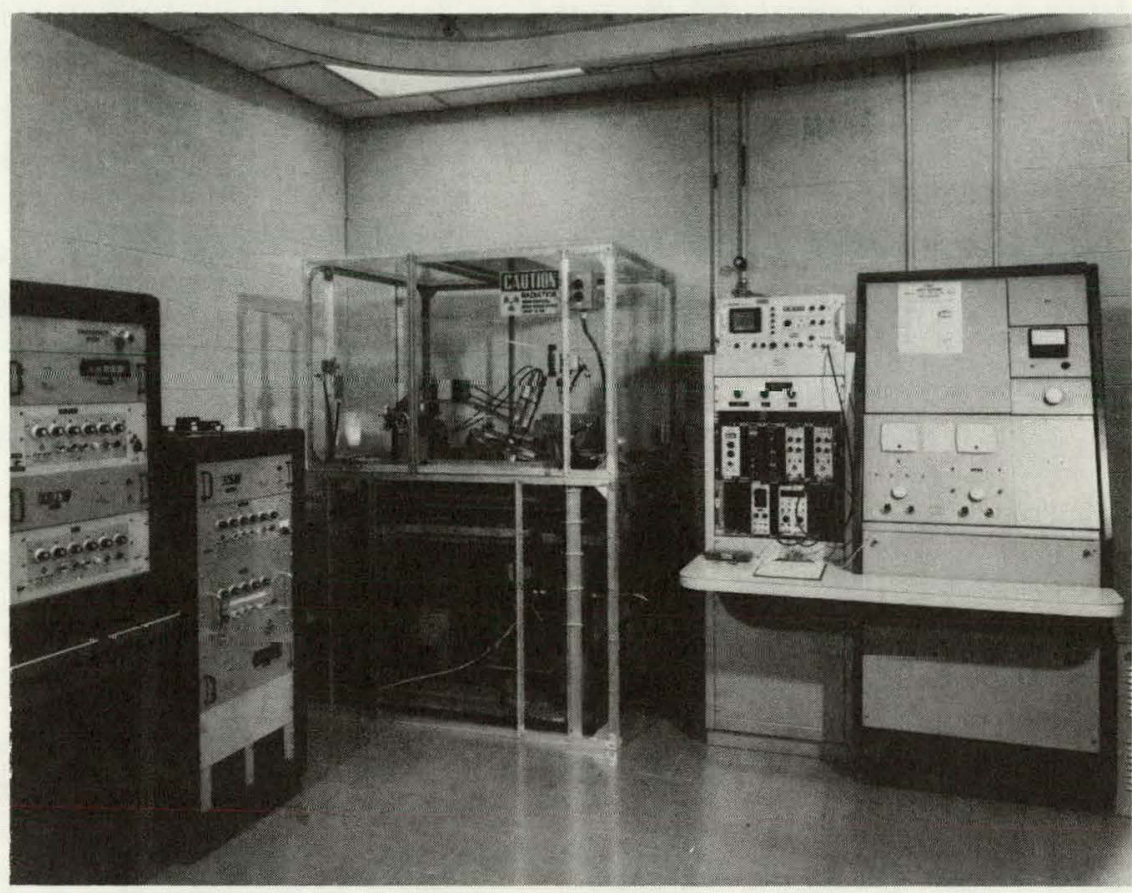

175665

Figure 2. OVERALL VIEW OF THE ENTIRE MEASUREMENT SYSTEM.

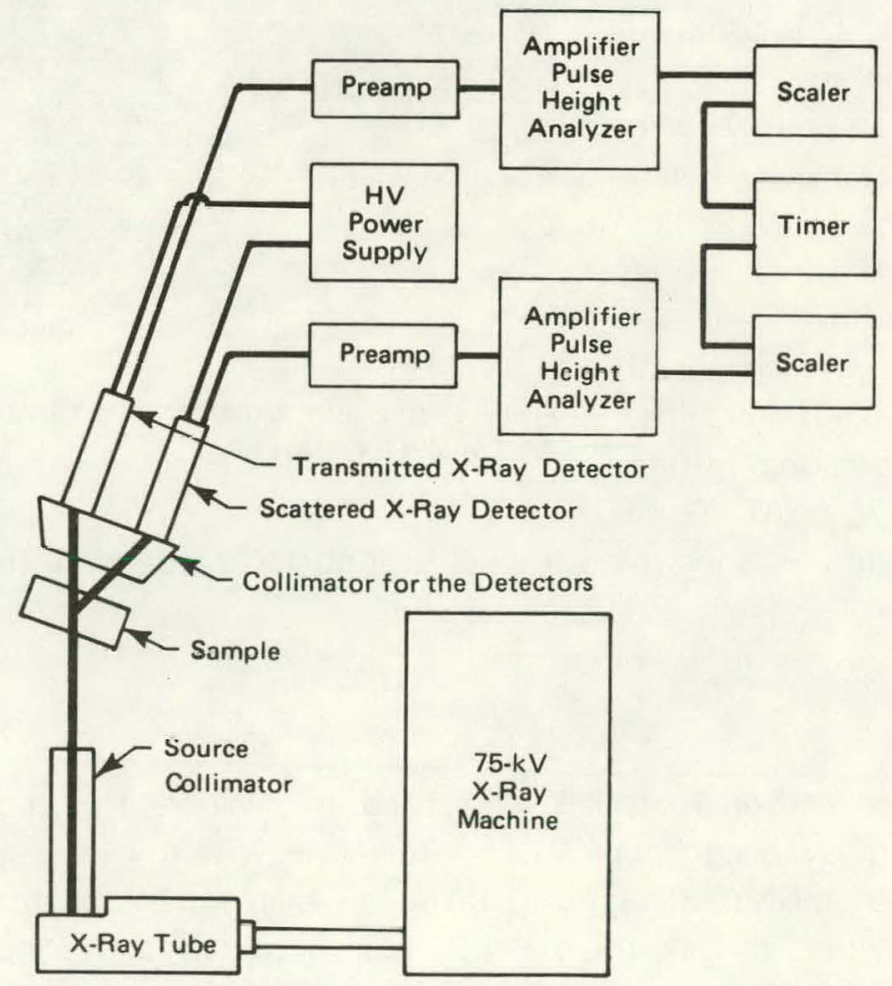

Figure 3. PRINCIPAL COMPONENTS OF THE DENSITY MEASUREMENT SYSTEM. 
GE-75 X-ray tube having a tungsten target and a beryllium window. The source collimator with a builtin, remotely operated shutter is mounted to the X-ray tube and is situated below a remotely operated sample handler. Measurement of transmitted and scattered beam intensities is accomplished with two standard scintillation-type detector systems. Each detector, an Nal (TI) crystal optically coupled to a photomultiplier tube, is used in conjunction with a preamplifier, amplifier, scaler, and timer. The detectors are mounted to a collimator that is positioned above the sample handler. Two slits in the collimator, one for each detector, collimate the transmitted and scattered $X$ rays to be counted. They form an angle of 45 degrees and focus at a point 3 $\mathrm{cm}$ below the bottom surface of the collimator. Figure 4 is a view of the detectors, collimators, and sample handler.

The bremsstrahlung radiation produced in an X-ray tube has a broad energy distribution. In order to narrow this distribution and form a peak-shaped incident beam spectrum, it was necessary to filter the incident beam. A tin/nickel combination is being used for this filter. This combination was chosen because $L X$ rays from the tungsten target were interfering with the measurement. The tin filter shapes a 26-keV $X$-ray peak, and the nickel filter separates that peak from the tungsten $\mathrm{L}$ X-ray peak. Figure 5 shows the resulting spectra (for $X$-ray machine operating settings

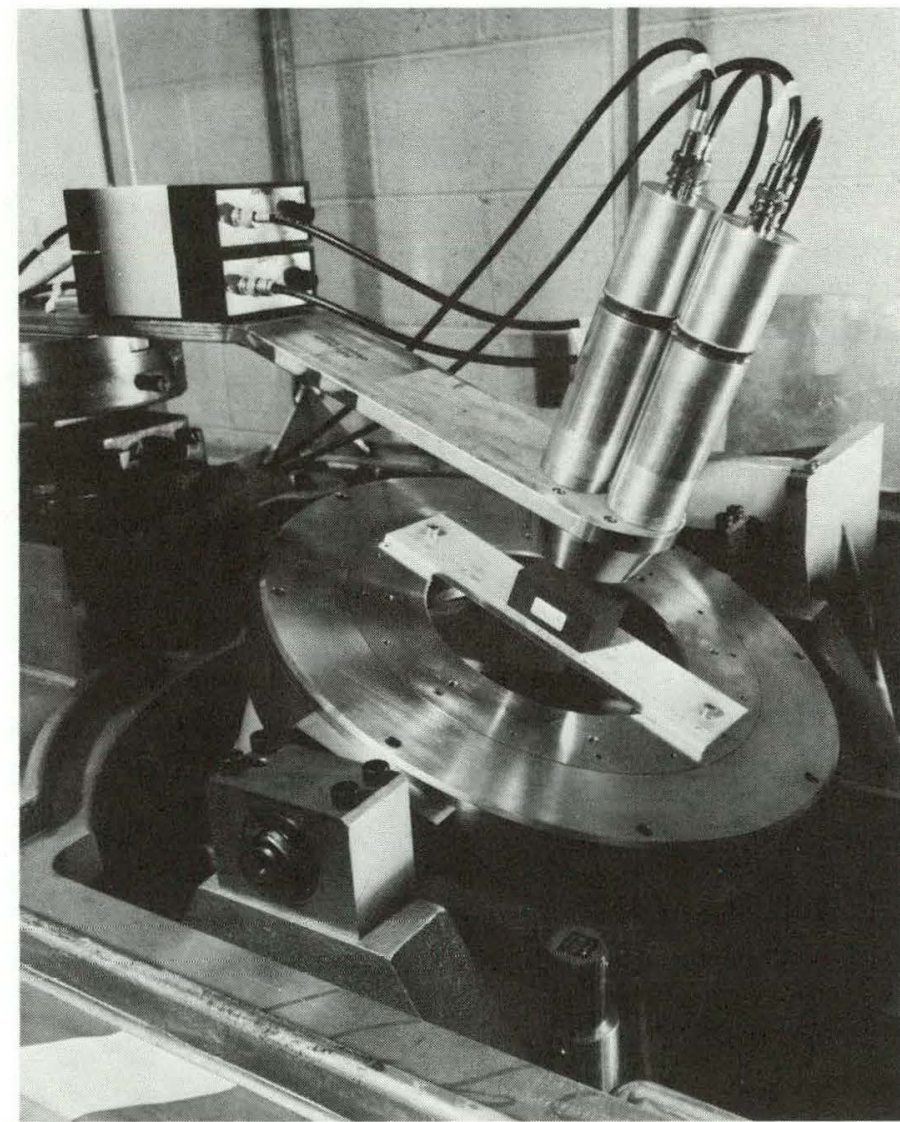

175663

Figure 4. CLOSEUP VIEW OF THE DETECTORS, COLLIMATORS, AND SAMPLE HANDLER. of $40 \mathrm{kV}$ and $70 \mathrm{~mA}$ ). Pulseheight discrimination is then used to select only $X$ rays from the $26-k e V$ peak for counting.

\section{EVALUATION}

Samples of pressed carbon materials were used to evaluate this measurement concept. Sample bulk densities ranged from 0.21 to $0.86 \mathrm{~g} / \mathrm{cm}^{3}$, with thicknesses ranging from 1.9 to $4.4 \mathrm{~cm}$. A series of measurements were taken on each sample at different positions, but maintaining a constant measurement depth (depth of the scattering volume within the sample) of $1 \mathrm{~cm}$. A measurement consisted of monitoring the $\mathrm{I}_{\mathrm{S}}$ and $\mathrm{I}_{\mathrm{t}}$ simultaneously for a 


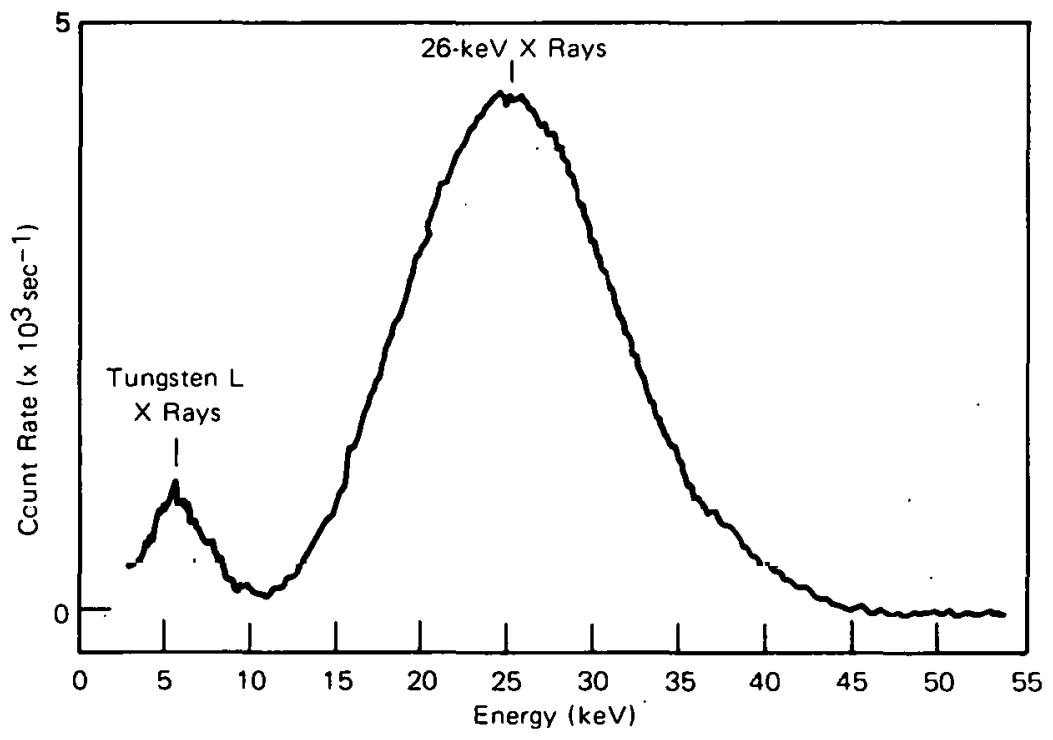

Figure 5. SPECTRUM OF THE INCIDENT X-RAY BEAM.

1000-second count time and then taking the $\mathrm{I}_{\mathrm{S}} / \mathrm{I}_{\mathrm{t}}$ ratio. The average measurement for each sample was then plotted against the sample's bulk density. The result was the expected linear relationship between $\mathrm{I}_{\mathrm{S}} / \mathrm{I}_{\mathrm{t}}$ and density. A straight-line fit to the data points is seen in Figure 6. Adjacent to each point is the sample thickness in centimeters. Clearly, the variations in sample thickness had no effect on the linearity of the fit. The maximum deviation from the fit was $0.8 \%$, with a correlation coefficient of 0.9998 . (A value of 0 means that no correlation exists and a value of 1 represents a perfect fit.) The measurement precision $(1 \sigma)$, based on counting statistics for a 1000 -second count time, was better than $0.5 \%$.

From the measurements taken on each sample, the variations in density were established. The maximum variation in density for each sample was then plotted against the bulk density. The

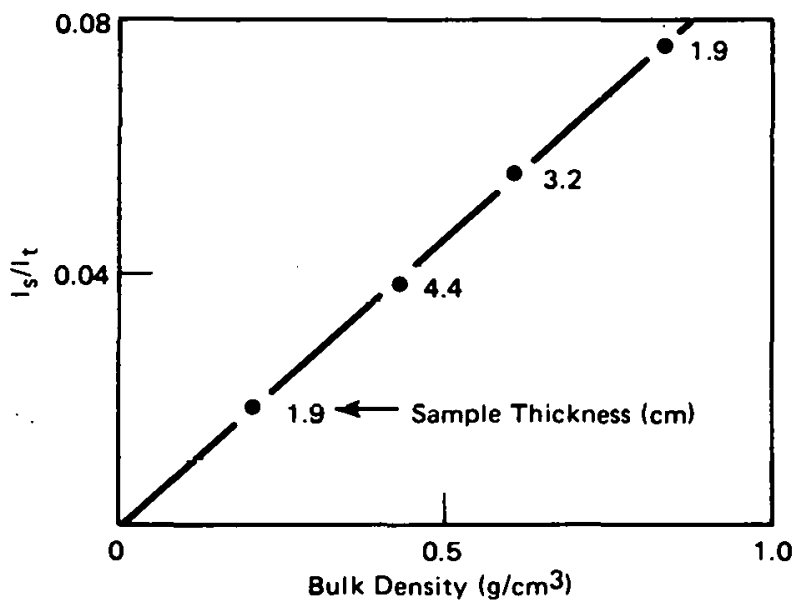

Figure 6. PLOT OF THE I $_{s} / 1_{t}$ RATIO AS A FUNCTION OF THE BULK DENSITY FOR PRESSED CARBON SAMPLES. results are reported in Figure 7. As seen, samples with the higher bulk densities have smaller density variations. This relationship is reasonable because, as the theoretical density of the material is approached the variatıons in density are expected to decrease.

\section{CONCLUSIONS}

The scope of this discussion has been limited to results obtained from work that was done at a constant measurement depth. It is appropriate here to point out that measurements taken 
at various measurement depths have demonstrated that the measurement response changes with a changing measurement depth. However, the measurement concept has been verified and, with sufficient precision to be a useful tool, the technique can be calibrated to provide density measurements at any given sample depth, or simply used to determine relative variations in density at any given depth.

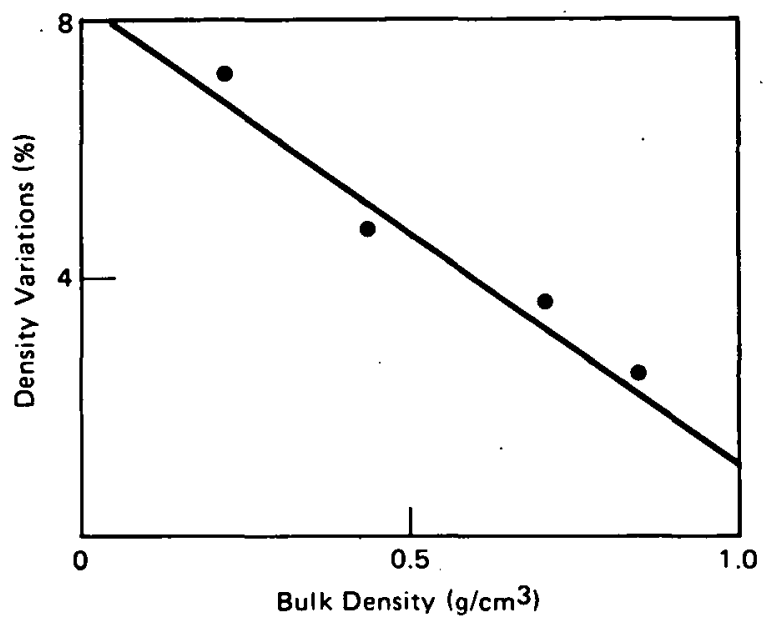

Figure 7. PLOT OF DENSITY VARIATIONS AS A FUNCTION OF THE BULK DENSITY FOR PRESSED CARBON SAMPLES. 


\section{ACKNOWLEDGEMENTS}

Special recognition should be given to S. G. Snow for his development of this measurement concept and to J. L. Cochran for his technical assistance in evaluating this concept. 


\section{Distribution}

Department of Energy - Oak Ridge

Hickman, H. D.

Leed, R. E.

Zachry, D. S., Jr

Lawrence Livermore Laboratory

Carr, R.,B.

Dittmañ, G. L./Jepson, J. O.

Grosclose, C.

MacMillan, K.C.

Nelson, W. E.

Root, G. S.

West, J. J./Chapman, W. H.

Los Alamos Scientific Laboratory

Burns, J. J./Baker, F. B.

Fulbright, $H$. J.

Hoyt, H. C.

Wechsler, J. J.

Oak Ridge Gaseous Diffusion Plant

Stief, S. S.

Wilcox, W. J., Jr

Oak Ridge National Laboratory

McClung, R.W.

Weir, J. R., Jr

Oak Ridge Y-12 Plant

Alvey, H. E.

Armstrong, R. C.

Bailey, H. L.

Bright, G. R.

Bernander, N. K.

Briscoe, O. W.

Burditt, R. B.

Cochran, J. L.

Cuddy, L. M.

Dodson, W. H./Googin, J. M.

Duggan, H. G.

Foulk, D. L.

Fraser, R. J.

Giacomelli, E. J. (5)

Jackson, V.C.

Jones, F.W.
Kahl, K. G.

Keith, A.

Kite, H. T.

Lambdin, F./Baylor, R.

Long, P. J.

Mason, D. L./Snow, S. G.

McLendon, J. D.

Neeley, A. C.

Phillips, L. R.

Sissom, D. T.

Smith, R. D.

Stoner, H. H.

Tewes, W. E.

$Y-12$ Central Files (master copy)

$Y-12$ Central Files (route copy)

$Y-12$ Central Files ( $Y-12 R C)$

$Y-12$ Central Files (5)

Paducah Gaseous Diffusion Plant

Bewley. H. D.

Sandia - Albuquerque

Burchett, O.J.

Sandia - Livermore

Henry, K. W.

Willis, A. R.

Union Carbide Corporation - New York

Tinsley, S. W.

In addition, this report is distributed in accordance with Category UC-37, Instruments, as given in the USERDA Standard Distribution Lists for Unclassified Scientific and Technical Reports, T1D-4500. 